\title{
Procurement and Management of Cord Blood
}

\author{
Sergio Querol and Vanderson Rocha
}

\subsection{Introduction}

Umbilical cord blood (UCB) cells for allogeneic use are collected and frozen in more than 130 public $\mathrm{CB}$ banks worldwide. More than seven hundred and fifty thousands $\mathrm{CB}$ units (CBU) are available for transplantation. In this chapter we will describe some procedures for cord blood collection, processing, banking and recommendations on how to choose a single or double UCB unit for transplantation (Garcia 2010).

\subsection{Collection}

Donor recruitment usually starts during the antenatal period, with objective information given by woman's health-care provider. After consent, trained personnel need to determine donor eligibility to ensure that donation is safe for future patients. To assess donor eligibility, a donor medical history interview shall be conducted identifying risk factors for transmissible and genetic disease. In addition, infectious disease markers (IDM) performed to maternal blood samples will be obtained within

\footnotetext{
S. Querol $(\bowtie)$

Banc Sang i Teixits, Barcelona, Spain

e-mail: squerol@bst.cat

V. Rocha

University of São Paulo, São Paulo, Brazil

University of Oxford, Oxford, UK
}

7 days before or after the collection of the UCB unit. These samples will be tested for evidence of infection of HIV-1, HIV-2, hepatitis B, hepatitis C, HTLV-I, HTLV-II, syphilis and any additional markers according to local regulations.

Collection must not interfere with normal delivery attention. A successful collection should have a high collection volume and a high total nucleated cell count, be non-contaminated and have the proper documentation. A UCB collection typically involves cord clamping (delayed clamping up to 1-2 min is still compatible with public donations) (Frändberg et al. 2016), disinfection, venipuncturing of umbilical vein and draining by gravity avoiding clotting. Collection bag should be appropriately labelled.

There are two main techniques to collect UCB from the cord vein: before the placenta is delivered (in utero) or after the placenta is delivered (ex utero). Both collection techniques have their own unique advantages and disadvantages, but both techniques require that the individuals performing the collections be adequately trained.

After collection, typically health-care provider will complete a report describing labour and completing variables that could be useful to release the unit like the presence of fever, complications, type of delivery, etc. In case of unexpected adverse reactions during collection they need to be communicated to the competent authority. After collection, it may be required a follow-up of the donor including health questionnaires. Additionally, if 
any abnormal result is detected during testing, a counseling process should be in place.

UCB units shall be transported to the processing facility, and sometimes, these facilities could be far away from the collection sites. A validated procedure for transportation between these two facilities is needed to demonstrate a reliable method. Standard procedures shall be in place to describe time and temperature of storage and transportation methods. All transportation records shall allow tracking back from the collection site to the UCB bank, and any deviation should be recorded.

\subsection{Processing and Banking}

\subsubsection{UCB Cell Processing}

Unrelated UCB unit must arrive at the processing laboratory in time to allow initiation of cryopreservation within $48 \mathrm{~h}$ of collection (this time is extended to $72 \mathrm{~h}$ for related or directed UCB donations). The decision as to whether a collected UCB unit will be acceptable for processing and banking will be made based on the acceptance criteria specified by the UCB bank. Many banks have further refined their acceptance criteria based on economics and the desire to build an international inventory of UCB units with very high TNC or percentage of ethnic minorities. Many UCB banks are now committed to processing and storing only those UCB units with high TNC (e.g. $>20 \times 10^{7} \mathrm{TNC}$ or higher), based on the greater likelihood of these units being used (Saccardi et al. 2016).

Volume reduction of UCB is considered essential to the provision of a high-quality product and cost-effective UCB banking. Reducing the volume of the final product allows for storage efficiency in terms of space and cost and, most importantly, reduces the risk of $\mathrm{ABO}$ incompatibility and DMSO toxicity to the potential recipient. Despite some loss of cells, volume reduction has additional practical and clinical benefits; the process yields RBC and plasma components as waste products that can be used for immediate or future testing, thereby minimizing the loss of the actual stem cell product for testing purposes.
Different methods for volume reduction are available (Hough et al. 2016).

The selection of a suitable protocol for cryopreservation of UCB for use in transplantation is critical to optimize the recovery of functionally viable progenitor cells, most of which lie within the $\mathrm{CD} 4^{+}$compartment. Some important considerations that are potential sources of cell damage include the type and concentration of cryoprotectant, the cell concentration and the cooling and warming rates. UCB units must be stored in freezing bags designed and approved for the cryopreservation of human cells and placed into metal canisters to afford protection during freezing, storage, transportation and shipping. It is important that after filling, each freezing bag is visually examined for possible leaking and breakage of seals.

UCB units should be cryopreserved using a controlled rate freezer with a validated freezing programme. Liquid nitrogen-based controlled rate freezers have been used to ensure long-term maintenance. Minimizing transient-warming events is very important for that. Stability programmes should be designed in order to establish the expiration time of the UCB stored.

\subsubsection{Testing and Quality Assessment}

Table 18.1 shows release specification for UCB units. Quality assessment is written below:

Safety It is essential that UCB is screened for those infectious diseases which can be transmitted via blood (as described above). In addition, product should be free of microbial contamination (or with an appropriate antibiogram for related uses). Prior to release for administration, each UCB unit must have undergone hemoglobinopathy screening.

Identity At least, HLA-A, HLA-B, HLA-C and DRB1 loci must be determined using DNAbased methods and result included when listing a UCB unit on the search registries. It is recommended that HLA typing is performed in an accredited laboratory. ABO blood group and $\mathrm{Rh}$ type must be reported prior to listing a UCB 
Table 18.1 Lists the specification requirements for CBU stored for clinical application, according to the sixth edition NetCord-FACT International Standards for Cord Blood Collection, Banking, and Release for Administration (www. factwebsite.org)

\begin{tabular}{|c|c|c|c|c|}
\hline \multicolumn{5}{|c|}{ Specification requirements for cord blood units stored for clinical administration } \\
\hline \multirow[b]{2}{*}{ Test } & \multicolumn{2}{|l|}{ Unrelated specification } & \multicolumn{2}{|l|}{ Related specification } \\
\hline & $\begin{array}{l}\text { Fresh post- } \\
\text { processing sample }\end{array}$ & $\begin{array}{l}\text { Post-thaw attached } \\
\text { segment or } \\
\text { representative sample } \\
\text { prior to release }\end{array}$ & $\begin{array}{l}\text { Fresh post-processing } \\
\text { sample }\end{array}$ & $\begin{array}{l}\text { Post-thaw attached } \\
\text { segment or } \\
\text { representative sample } \\
\text { prior to release }\end{array}$ \\
\hline $\begin{array}{l}\text { Total nucleated } \\
\text { cell count }\end{array}$ & $\geq 5.0 \times 10^{8}$ & & Enumerated & \\
\hline $\begin{array}{l}\text { Total nucleated } \\
\text { cell recovery }\end{array}$ & Should be $\geq 60 \%$ & & Should be $\geq 60 \%$ & \\
\hline Total viability & $\geq 85 \%$ & & $\geq 70 \%$ & \\
\hline $\begin{array}{l}\text { Viable CD34 } \\
\text { count }\end{array}$ & $\geq 1.25 \times 10^{6}$ & & & \\
\hline $\begin{array}{l}\text { Viability of } \\
\text { CD34 cells }\end{array}$ & $\geq 85 \%$ & $\geq 70 \%$ & $\geq 85 \%$ & $\geq 70 \%$ \\
\hline $\begin{array}{l}\text { Viability of } \\
\text { CD } 45 \text { cells }\end{array}$ & & $\geq 40 \%$ & & $\geq 40 \%$ \\
\hline $\begin{array}{l}\text { CFU (or other } \\
\text { validated } \\
\text { potency assay) }^{\mathrm{a}}\end{array}$ & & $\begin{array}{l}\text { Growth (or positive } \\
\text { result for potency) }\end{array}$ & & $\begin{array}{l}\text { Growth (or positive } \\
\text { result for potency) }\end{array}$ \\
\hline Sterility & $\begin{array}{l}\text { Negative for aerobes, } \\
\text { anaerobes, fungus }\end{array}$ & & $\begin{array}{l}\text { Negative for aerobic and } \\
\text { anaerobic bacteria and } \\
\text { fungi-OR-identify and } \\
\text { provide results of } \\
\text { antibiotic sensitivities }\end{array}$ & \\
\hline $\begin{array}{l}\text { Donor screening } \\
\text { and testing }\end{array}$ & $\begin{array}{l}\text { Acceptable as } \\
\text { defined by } \\
\text { Applicable Law and } \\
\text { NetCord-FACT } \\
\text { standards }\end{array}$ & & $\begin{array}{l}\text { Acceptable as defined by } \\
\text { Applicable Law and } \\
\text { NetCord-FACT standards }\end{array}$ & \\
\hline Identity & & Verified & & Verified \\
\hline
\end{tabular}

unit for search. Prior to release of a UCB unit for administration, it is imperative that HLA identity is confirmed. Ideally, confirmatory typing will be performed on a sample taken from a contiguous segment. HLA typing on maternal blood may also be performed prior to release of a UCB unit. Haplotype matching between maternal donor and infant donor confirms linkage between the two and serves as a secondary confirmation of identity.

Purity UCB unit specifications report total nucleated cells, total nucleated RBC count and CD34+ cells, and a cell blood count with differential should be performed, with parameters for neutrophils, lymphocytes, monocytes and platelets defined.
Potency Potency testing to determine the growth potential and viability of progenitor cells in a UCB unit should be performed post-processing (prior to cryopreservation), in addition to being performed on a representative thawed sample prior to release for administration.

\subsection{Selecting CBU for Transplantation}

The success of the UCB transplantation (UCBT) will depend on the characteristics of the CBU. Tables 18.2 and 18.3 list the recommendation of choosing single and double cord blood units, respectively, for transplantation. 
Table 18.2 Recommendations for unrelated CBU selection and transplantation ${ }^{\mathrm{a}}$

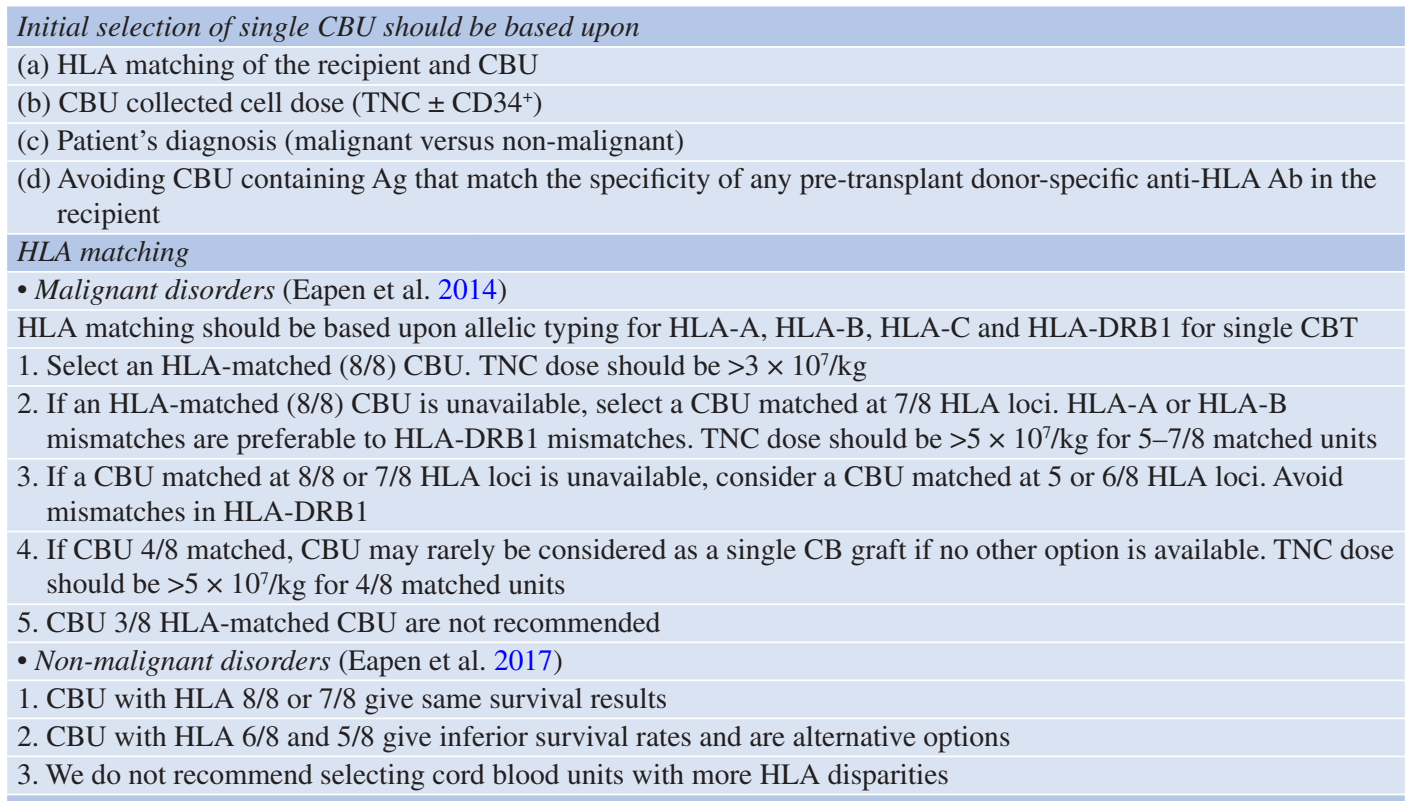

TNC and $C D 34^{+}$cell dose

- Malignant disorders

Nucleated cell dose $\mathrm{e}^{\mathrm{b}}$

At freezing, minimum TNC dose $3.0 \times 10^{7} / \mathrm{kg}$, or

$\mathrm{CD}_{34}{ }^{+}$cell dose $\mathrm{c}^{\mathrm{C}}$ After thawing, minimum TNC of $2.0-2.5 \times 10^{7} / \mathrm{kg}$

At freezing, $1.0-1.7 \times 10^{5} / \mathrm{kg}$, or

After thawing, around $1.0-1.2 \times 10^{5} / \mathrm{kg}$

- Non-malignant disorders ${ }^{\mathrm{d}}$

Nucleated cell dose

At freezing, minimum cell dose $3.5 \times 10^{7} / \mathrm{kg}$, or

After thawing, minimum cell dose $3.0 \times 10^{7} / \mathrm{kg}$

CD $34^{+}$cell dose

At freezing or after thawing, $>1.7 \times 10^{5} / \mathrm{kg}$

Colony-forming unit assay: This assay is important to evaluate the functional capacity of HPCs after thawing an aliquot or after thawing the product; however it is difficult to establish a generalized CFU-GM dose due to variations of colony setup and counting between centres

\section{Other considerations when selecting single $C B$ units}

If many CBU meeting the criteria above are available, the following factors should also be considered

- Use accredited cord blood banks. For safety, only accredited banks recognized by national and international organizations should be used

- ABO compatibility: $\mathrm{ABO}$ compatibility may be associated with improved outcomes, although the data are conflicting

- NIMA: If the cord banks have the mother's HLA typing, the potential effect of NIMA should be noted in context of clinical trials

- KIR ligand: Due to conflicting data, KIR ligand matching should not be used in the selection of CBUs

- Sex matching: Sex matching between CBUs and patients in single or double UCBT is not necessary

aBased on Eurocord and British Society of Blood and Marrow Transplantation recommendations (Hough et al. 2016, modified)

${ }^{b}$ If the infused TNC dose is $1.0-2.0 \times 10^{7} / \mathrm{kg}$, the number of CD34+ cells or CFU-GM should be taken into consideration to predict the probability of neutrophil recovery and to discuss the possibility of a second transplant. If both cell doses are lower than recommended, a BM aspirate and chimerism analysis should be performed between days $+20-28$. The absence of engraftment indicates the need for a second transplant; preliminary data shows that haploidentical or double CBT should be considered

'Due to variation in counting CD34+ cells, this recommendation should be taken with caution. However, if colonies are not growing, the transplant physicians should consider a second transplant after day +30

${ }^{\mathrm{d}}$ For patients with BMF syndromes (aplastic anaemia or congenital bone marrow failure states) or haemoglobinopathies, the number of TNC at freezing should be greater than $5 \times 10^{7} / \mathrm{kg}$ 
Table 18.3 Additional criteria for double CBU selection

- When a single CBU unit contains insufficient cells (as specified above), double UCBT is recommended for the treatment of malignant disorders

- There are currently insufficient data to make recommendations for double UCBT in the treatment of nonmalignant disorders

\section{HLA matching}

- The historical stringency of HLA matching for CBUs with the recipient for double UCBTs should be used, i.e. the minimum acceptable HLA matching between either CBU and the recipient is 4/6 using low/intermediate typing (antigen) for HLA-A and HLA-B and high- resolution typing (allelic) for HLA-DRB1

- There is no requirement for inter-cord HLA matching

- The role of high-resolution (allele) typing is not yet defined for double CBT

Cell dose

Nucleated cell dose At freezing, the sum of both CBUs $>3.5 \times 10^{7} / \mathrm{kg}$

$\mathrm{CD} 34^{+}$cell dose The minimum cell dose of each unit should be $>1.5 \times 10^{7} / \mathrm{kg}$

ABO matching At freezing or after thawing, the sum of both CBUs $>1.8 \times 10^{5} / \mathrm{kg}$

Recently, a retrospective study of Eurocord of almost 1000 double UCBT recipients has shown an important association between $\mathrm{ABO}$ compatibility of 2 units with the patient on acute GVHD, NRM and OS. Thus, ABO compatibility between units and patients should be preferred over minor or major compatibility of one of the units between CB and patient (V Rocha on behalf of Eurocord, personal recommendation)

\section{Key Points}

- Cord blood donation comprises the following steps: informative and consent process, revision of eligibility criteria, cord blood collection and finally fresh storage before a standardized transportation to the processing cell lab.

- Cell processing labs require coordination of production and quality control labs to transform the altruistically donated raw material in a medicinal product with predefined specifications that ensure its safety, identity, purity and potency.

- A public cord blood bank is a stem cell registry that provides ready-to-use banked medicinal products for any patient in need through international networking of stem cell donor organizations.

- Cord blood selection is based on sorting CB units using primary criteria (cell content and HLA matching) followed by ranking based in secondary criteria depending on disease status, conditioning, age and recipient's weight.

\section{References}

Eapen M, Klein JP, Ruggeri A, Spellman S, Lee SJ, Anasetti C, Arcese W, Barker JN, Baxter-Lowe LA, Brown M, Fernandez-Vina MA, Freeman J, He W, Iori AP, Horowitz MM, Locatelli F, Marino S, Maiers M, Michel G, Sanz GF, Gluckman E, Rocha V, Center for International Blood and Marrow Transplant Research, Netcord, Eurocord, and the European Group for Blood and Marrow Transplantation. Impact of allele-level HLA matching on outcomes after myeloablative single unit umbilical cord blood transplantation for hematologic malignancy. Blood. 2014;123: 133-40.

Eapen M, Wang T, Veys PA, Boelens JJ, St Martin A, Spellman S, Bonfim CS, Brady C, Cant AJ, Dalle JH, Davies SM, Freeman J, Hsu KC, Fleischhauer K, Kenzey C, Kurtzberg J, Michel G, Orchard PJ, Paviglianiti A, Rocha V, Veneris MR, Volt F, Wynn R, Lee SJ, Horowitz MM, Gluckman E, Ruggeri A. Allele-level HLA matching for umbilical cord blood transplantation for non-malignant diseases in children: a retrospective analysis. Lancet Haematol. 2017;4:e325-33.

Frändberg S, Waldner B, Konar J, Rydberg L, Fasth A, Holgersson J. High quality cord blood banking is feasible with delayed clamping practices. The eightyear experience and current status of the national Swedish Cord Blood Bank. Cell Tissue Bank. 2016;17(3):439-48.

Garcia J. Allogeneic unrelated cord blood banking worldwide: an update. Swedish bank reference delay clamping. Transfus Apher Sci. 2010;42:257-63. 
Hough R, Danby R, Russell N, Marks D, Veys P, Shaw B, Saccardi R, Tucunduva L, Ruggeri A, Ionescu I, Koegler Wynn R, Vora A, Mackinnon S, Peggs KS, Crawley C, Craddock C, Pagliuca A, Cook G, Snowden JA, Clark A, Marsh J, Querol S, Parkes G, Braund H, Rocha V. Recommendations for a standard UK approach to incorporating umbilical cord blood into clinical transplantation practice: an update on cord blood unit selection, donor selection algorithms and conditioning protocols. Br J Haematol. 2016;172:360-70. G, Querol S, Grazzini G, Lecchi L, Nanni Costa A, Navarrete C, Pouthiers F, Larghero J, Regan D, Freeman T, Bittencourt H, Kenzey C, Labopin M, Baudoux E, Rocha V, Gluckman E. Impact of cord blood banking technologies on clinical outcome: a Eurocord/Cord Blood Committee (CTIWP), European Society for Blood and Marrow Transplantation and NetCord retrospective analysis. Transfusion. 2016;56:2021-9.

Open Access This chapter is licensed under the terms of the Creative Commons Attribution 4.0 International License (http://creativecommons.org/licenses/by/4.0/), which permits use, sharing, adaptation, distribution and reproduction in any medium or format, as long as you give appropriate credit to the original author(s) and the source, provide a link to the Creative Commons license and indicate if changes were made.

The images or other third party material in this chapter are included in the chapter's Creative Commons license, unless indicated otherwise in a credit line to the material. If material is not included in the chapter's Creative Commons license and your intended use is not permitted by statutory regulation or exceeds the permitted use, you will need to obtain permission directly from the copyright holder. 